\title{
Skill Mismatch yang Dirasakan oleh Alumni Program Studi Diploma IV Akuntansi Politeknik Negeri Padang
}

\author{
Annice Azalia1 ${ }^{1}$, Josephine Sudiman², dan Ulfi Maryati3* \\ 1 Jurusan Akuntansi, Politeknik Negeri Padang \\ Email: anniceazalia.aa@gmail.com \\ ${ }^{2}$ Jurusan Akuntansi, Politeknik Negeri Padang \\ Email: jsudiman@pnp.ac.id \\ 3Jurusan Akuntansi, Politeknik Negeri Padang \\ Email:ulfimaryati@gmail.com \\ *Corresponding Author
}

\begin{abstract}
Many previous studies found that there was dissatisfaction with graduate users with the competencies possessed by Accounting graduates. Importantly, Accounting graduates must prepare themselves for various competencies needed in the world of work. This purpose of this study is to examine whether there is a competency gap faced by the graduates of Accounting Department of the Padang State Polytechnic while performing their first job. This study uses a quantitative method. Sample selected purposively on the alumni of D-IV 4 Accounting at the Padang State Polytechnic with 54 respondents that had worked after graduation. The data analysis technique in this study used the sign test and the Mann-Whitney U test. The results show that there is a competency gap faced by alumni in the attributes of technical and IT skills except in presenting financial reports, planning and conducting audits, implementing internal controls, measuring company performance, using Office, accounting software and social media. There is also no difference found in competency level between graduates of 2019 and 2020.
\end{abstract}

Keywords: skills, attributes, alumni, gap, work

\begin{abstract}
ABSTRAK
Banyaknya penelitian terdahulu menemukan adanya ketidakpuasan pengguna lulusan terhadap kompetensi yang dimiliki oleh lulusan Akuntansi baru. Untuk itu, pentingnya lulusan Akuntansi baru mempersiapkan diri dengan berbagai kompetensi yang dibutuhkan di dunia kerja. Penelitian ini bertujuan untuk menguji apakah terdapat gap kompetensi yang dihadapi oleh alumni D-IV Akuntansi Politeknik Negeri Padang pada pekerjaan pertama. Penelitian ini menggunakan metode kuantitatif. Sample dipilih secara purposive pada alumni D-IV 4 Akuntansi Politeknik Negeri Padang dengan responden sebanyak 54 orang yang sudah pernah bekerja setelah lulus. Teknik analisis data dalam penelitian ini menggunakan sign test dan Mann-Whitney $U$ test. Hasil penelitian menunjukkan terdapat gap kompetensi yang dihadapi oleh alumni pada atribut keterampilan teknis dan TI kecuali dalam menyajikan laporan keuangan, merencanakan dan melakukan audit, melakukan pengendalian internal, menghitung kinerja perusahaan, serta menggunakan Microsoft Office, software Akuntansi, dan media sosial. Selain itu, tidak terdapat perbedaan kompetensi yang dimiliki alumni angkatan alumni angkatan tahun 2019 dan 2020.
\end{abstract}

Kata kunci: keterampilan, atribut, alumni, gap, pekerjaan 


\section{Pendahuluan}

Berdasarkan pada Visi Indonesia 2045 dan Rencana Pembangunan Jangka Menengah Nasional (RPJMN) 2020-2024, Pemerintah Indonesia sedang berupaya untuk menghasilkan sumber daya manusia (SDM) yang unggul, berbudaya serta menguasai ilmu pengetahuan dan teknologi. Dengan adanya SDM yang berkualitas diharapkan ekonomi Indonesia tumbuh maju dan berkelanjutan serta pembangunan semakin merata. Selain itu, adanya harapan Indonesia menjadi negara yang semakin demokratis, kuat dan bersih. Visi Indonesia 2045 menjadi pegangan penting dalam mengarahkan pembangunan menuju Indonesia emas. Hal ini dilakukan untuk memperingati 100 tahun Indonesia merdeka nantinya [17].

Saat ini, kebutuhan tenaga kerja terampil, kreatif, inovatif dan adaptif di Indonesia belum dapat dipenuhi secara optimal. Berdasarkan Global Human Capital Index (2017), Indonesia berada di posisi 65 dari 130 negara masih tertinggal dibandingkan negara Asia Tenggara lainnya yaitu Malaysia (peringkat 33), Thailand (peringkat 44) dan Vietnam (peringkat 64) [18]. Kualitas tenaga kerja yang rendah dan belum merespons perkembangan kebutuhan pasar kerja menjadi salah satu penyebab produktivitas dan daya saing Indonesia masih rendah. Hal ini juga dapat dilihat dari tingkat pengangguran sampai Februari 2021 sebesar 6,26\%. Jumlah pengangguran terbuka berdasarkan pendidikan diploma I/II/III sebesar $6,61 \%$ sedangkan sarjana sebesar 6,97\% (BPS, 2021) [2].

Menurut Sudono dan Lingga (2019) dalam website ILO mengungkapkan ketidakcocokan keterampilan (skill mismatch) juga menjadi salah satu penyebab tidak terserapnya lulusan di Indonesia [15]. Untuk itu, pentingnya peran perguruan tinggi untuk menghasilkan lulusan yang memiliki kualifikasi dan kompetensi memadai yang dibutuhkan oleh dunia usaha dan dunia industri (DUDI). Salah satu cara untuk meningkatkan kompetensi melalui pendidikan dan latihan sebagai sarana untuk pengembangan potensi diri agar berkualitas dan dapat menambah daya saing. Pendidikan dan latihan tidak saja menambah pengetahuan, akan tetapi juga meningkatkan keterampilan kerja. Dengan demikian, produktivitas kerja juga akan meningkat (Muhson et al., 2012) [12].

Politeknik sebagai pendidikan vokasi merupakan bagian penting dalam sistem pendidikan nasional yang bertujuan untuk menghasilkan tenaga kerja berkualitas. Hal ini berarti adanya tanggung jawab pendidikan vokasi untuk membangun kesadaran dan keterlibatan aktif dari DUDI. Keterlibatan aktif DUDI diharapkan bisa menghasilkan profil lulusan yang memiliki pengetahuan dan keterampilan tinggi (know-how and high-skilled) sesuai kebutuhan pemakai lulusan.

Jurusan Akuntansi merupakan salah satu dari 7 jurusan yang ada di Politeknik Negeri Padang. Jenjang pendidikan vokasi jurusan Akuntansi terdiri dari tiga yaitu Diploma III, Diploma IV dan Magister Terapan (S2). Visi dari Program Studi Diploma IV adalah menjadi institusi Program Studi Diploma IV Akuntansi yang unggul dan berwawasan internasional pada tahun 2023, sedangkan visi dari Program Studi Diploma III adalah menjadi institusi pendidikan vokasional unggulan bidang Akuntansi Program Diploma III di Asia Tenggara. Visi tersebut menjadi tantangan untuk mencari kenyataannya. Hal ini mengingat lulusan Akuntansi merupakan salah satu lulusan yang sudah jenuh. Setiap tahunnya, Indonesia menghasilkan sekitar 35.000 lulusan Akuntansi tapi tidak terserap oleh pasar tenaga kerja (IAI, 2014) [6]. Tidak hanya itu, banyak pengguna lulusan telah mengekspresikan ketidakpuasan mereka terhadap 
pengetahuan dan keterampilan yang diperlihatkan oleh fresh graduate ini. Padahal mereka memiliki peran aktif dalam dunia bisnis sehingga tidak terlepas dari perubahan lingkungan bisnis dan ekonomi.

Adanya tuntutan peningkatan kualifikasi lulusan Akuntansi untuk memberikan jasa profesional yang dimilikinya. Untuk itu, lulusan Akuntansi perlu memperhatikan keterampilan dan atribut yang harus mereka miliki sebagai modal untuk bersaing di pasar dunia kerja (Kurniawan, 2016) [10]. Pengklasifikasian keterampilan yang dilakukan oleh Klibi dan Oussii (2013) menjadi keterampilan teknis dan keterampilan generik yang digunakan oleh Kavanagh dan Drennan (2008) sebelumnya juga perlu diperhatikan [9]. Sebagai lulusan Akuntansi, mereka harus mampu menyediakan informasi yang dibutuhkan stakeholder yang berhubungan dengan laporan keuangan. Dengan harapan, informasi yang disampaikan memenuhi kriteria informasi Akuntansi yang diamanatkan SFAC 2 yaitu relevan, andal, daya banding dan konsisten, materialitas, serta mempertimbangkan biaya dan manfaat sehingga tidak menyesatkan penggunanya (FASB, 1980) [5].

Penelitian Singh dan Singh (2008) menemukan dunia usaha dan industri menilai bahwa rata-rata keterampilan lulusan Akuntansi masih belum sesuai dengan apa yang diinginkan oleh pemberi kerja [14]. Penelitian ini juga sejalan dengan hasil penelitian yang dilakukan oleh Kavanagh dan Drennan (2008). Hasil penelitiannya menyatakan bahwa dunia usaha dan industri mengharapkan pemahaman yang lebih baik akan keterampilan Akuntansi dan kemampuan analisis yang kuat dari mahasiswa serta pengetahuan mengenai dunia nyata yang lebih mendalam [8]. Hasil penelitian ini juga menunjukkan hasil yang sama dengan penelitian Tempone et al. (2012) yaitu keterampilan umum dari lulusan Akuntansi perlu ditingkatkan lagi [16]. Selain itu, hasil ini sejalan dengan penelitian yang dilakukan Abayadeera dan Watty (2014) bahwa banyak keterampilan umum tidak dicapai dan dimiliki oleh lulusan Akuntansi [1].

Berdasarkan pemaparan di atas, penyebab terjadinya pengangguran adalah skill mismatch dan banyaknya peneliti terdahulu menemukan kompetensi lulusan Akuntansi dari perguruan tinggi tidak memenuhi harapan pemberi kerja. Dengan demikian, peneliti tertarik untuk melakukan penelitian ini yang bertujuan untuk memeriksa apakah terdapat gap kompetensi yang dihadapi oleh alumni Program Studi Diploma IV Akuntansi Politeknik Negeri Padang (PS D-IV Akuntansi PNP) pada pekerjaan pertama. Perbedaan yang mencolok pada penelitian ini berupa sampel yang digunakan merupakan alumni program pendidikan vokasi, sedangkan penelitian terdahulu menggunakan sampel berupa alumni/mahasiswa yang berasal dari universitas.

\section{Teori kontingensi tindakan dan kinerja}

Pada tahun 1982, teori kontingensi tindakan dan kinerja pekerjaan pertama kali diperkenalkan oleh Boyatzis. Teori kinerja adalah dasar dari konsep kompetensi. Teori yang digunakan dalam pendekatan ini adalah teori kontingensi dasar, seperti yang ditunjukkan pada gambar 1 . Kinerja maksimal terjadi apabila kapabilitas individu sesuai dengan kebutuhan tuntutan pekerjaan dan lingkungan organisasi (Boyatzis, 2008). Teori ini mengambarkan persimpangan faktor organisasi dengan individu dan 
tuntutan pekerjaan di mana best fit (maximum performance, stimulation and commitment) yang mengidentifikasi prestasi kerja yang optimal [3].

Kapabilitas individu dijelaskan oleh nilai-nilai, visi, dan filosofi pribadi; pengetahuan; kompetensi; tahap kehidupan dan karier; minat; dan gaya. Tuntutan pekerjaan dapat digambarkan dengan tanggung jawab peran dan tugas yang perlu dilakukan. Aspek lingkungan organisasi yang diperkirakan memiliki dampak penting pada kompetensi dan/atau desain pekerjaan, perannya meliputi budaya dan iklim; struktur dan sistem; kematangan industri dan posisi strategis di dalamnya; dan aspek lingkungan organisasi (ekonomi, politik, sosial, lingkungan, dan agama). Pada penelitian ini, teori kontingensi tindakan dan kinerja dilihat dari aspek individu dan tuntutan pekerjaan pertama yang dimiliki oleh alumni PS D-IV Akuntansi PNP.

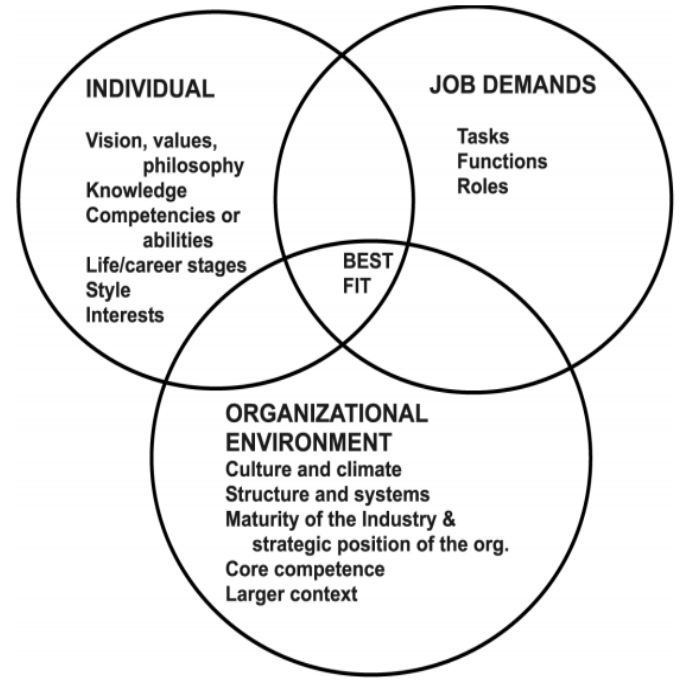

Gambar 1. Contingency Theory of Action and Job Performance Sumber : Boyatzis (2008)

\section{Pengembangan hipotesis}

Banyak studi sebelumnya telah dilakukan di berbagai negara yaitu Sri Lanka (Abayadeera \& Watty, 2014), Tunisia (Klibi \& Oussii, 2013), Amerika Serikat (Yu et al., 2013), Australia (Jackling \& De Lange, 2009; Kavanagh \& Drennan, 2008; Tempone et al., 2012), Malaysia (Singh \& Singh, 2008) dan New Zealand (Low et al., 2016) yang menyimpulkan bahwa adanya perbedaaan harapan pemberi kerja sebagai pengguna lulusan dengan keterampilan teknis dan umum yang ditampilkan oleh lulusan Akuntansi. Perbedaan harapan dengan realitas ini disebut juga dengan istilah kesenjangan ekspektasi-kinerja. [1], [9], [19], [7], [8], [16], [14], [11]

Keterampilan dan atribut yang dibutuhkan lulusan Akuntansi untuk memasuki dunia kerja tidak dikembangkan dengan baik pada tingkat perguruan tinggi (Bui \& Porter, 2010; Kavanagh \& Drennan, 2008) [4], [8]. Adanya harapan dari pemberi kerja mengenai pemahaman yang baik mengenai konsep Akuntansi dasar dan keterampilan generik. Keterampilan generik yang dimiliki lulusan Akuntansi belum sesuai dengan harapan pemberi kerja seperti kerja tim, keterampilan interpersonal dan komunikasi (Kavanagh \& Drennan, 2008; Klibi \& Oussii, 2013; Singh \& Singh, 2008) [9], [14]. Untuk itu, pentingnya meningkatkan keterampilan lulusan Akuntansi untuk memastikan 
lulusan dapat bekerja dengan baik di masa depan dan siap melakukan pembelajaran secara berkelanjutan (Singh \& Singh, 2008) [14].

Perguruan tinggi di Indonesia belum mengembangkan kompetensi lulusan secara maksimal sesuai dengan permintaan pengguna lulusan seperti masalah yang telah dijelaskan pada latar belakang sebelumnya. Selain itu, sesuai dengan hasil penelitian terdahulu ditemukan adanya gap kompetensi yang dialami oleh lulusan Akuntansi yang tidak memenuhi ekspektasi pemberi kerja. Untuk itu, pentingnya melakukan tracer study terhadap lulusan Akuntansi berdasarkan jenis pekerjaan, posisi dan keterampilan yang dimilikinya. Hal ini bertujuan untuk menguji apakah terdapat gap kompetensi yang dihadapi oleh lulusan Akuntansi. Dari pemaparan latar belakang dan hasil penelitian terdahulu dapat dikembangkan hipotesis dalam penelitian ini adalah:

H1 : Terdapat gap kompetensi yang dihadapi alumni PS D-IV Akuntansi PNP.

Sistem pembelajaran pada PS D-IV Akuntansi PNP didesain dengan proporsi $60 \%$ praktik dan $40 \%$ teori. Penerapan sistem praktik merupakan bentuk miniatur sistem di dunia usaha dan industri untuk menyiapkan lulusan Akuntansi yang terampil dan mempunyai etos kerja sesuai kebutuhan industri. Kurikulum berbasis kompetensi (KBK) dan disesuaikan dengan kerangka kualifikasi nasional Indonesia (KKNI) dirancang secara dinamis dengan memperhatikan kebutuhan pemakai lulusan. Kerja sama dengan industri diwujudkan dengan dilakukannya MoU dengan berbagai pengguna lulusan seperti Kantor Akuntan Publik (KAP), BUMN, BUMD, dan instansi pemerintah serta swasta.

Kurikulum yang digunakan pada PS D-IV Akuntansi PNP yaitu kurikulum 2014. Pada kurikulum ini jumlah mata kuliah yang harus diselesaikan oleh mahasiswa sebanyak 54 buah dengan 157 SKS. Untuk menyelesaikan mata kuliah tersebut dibutuhkan waktu 231 jam dalam jangka waktu 8 semester. Kurikulum 2014 ini masih digunakan oleh mahasiswa PS D-IV Akuntansi PNP angkatan tahun 2020. Dengan demikian, penelitian ini juga menguji apakah terdapat perbedaan kompetensi antara alumni PS D-IV Akuntansi PNP tahun 2019 dan 2020. Hal ini berhubungan dengan kurikulum PS D-IV Akuntansi PNP yang didapatkan alumni yang tamat tahun 2019 dan 2020 sama karena belum ada perubahan kurikulum saat itu, maka hipotesis yang dikembangkan adalah:

H2 : Tidak terdapat perbedaan kompetensi alumni PS D-IV Akuntansi PNP tahun 2019 dan 2020.

\section{Metode Penelitian}

\section{Desain penelitian}

Pendekatan penelitian yang digunakan berupa penelitian kuantitatif bertujuan untuk melihat gap kompetensi yang dihadapi oleh alumni PS D-IV Akuntansi PNP pada pekerjaan pertama. Data yang dikumpulkan berupa persepsi dari alumni mengenai penilaian tingkat kompetensi yang dimilikinya saat studi dibandingkan dengan tuntutan pekerjaan pertama. 


\section{Populasi dan sampel}

Populasi penelitian ini adalah alumni PS D-IV Akuntansi PNP. Dalam pengambilan sampel, peneliti menggunakan metode purposive sampling dengan kriteria alumni PS D-IV Akuntansi PNP dengan tahun tamat 2019 dan 2020 yang sudah pernah bekerja setelah lulus pada instansi pemerintah ataupun swasta. Pemilihan sampel ini didasarkan dengan alasan bahwa alumni yang tamat tahun 2019 dan 2020 terbilang masih baru memasuki dunia kerja dan belum mendapatkan pelatihan-pelatihan profesional secara berkelanjutan. Dengan demikian, alumni yang sudah pernah bekerja setelah lulus dapat membandingkan perbedaan kompetensi yang didapatkan selama perkuliahan dengan kebutuhan kompetensinya sesuai bidang pekerjaannya.

Jumlah alumni PS D-IV Akuntansi PNP tahun tamat 2019 dan 2020 menurut data pada sistem informasi akademik PNP berjumlah 100 orang. Setelah mendapatkan sampel yang dibutuhkan, kemudian disebarkan kuesioner penelitian melalui google form. Dari kuesioner yang telah disebar, hanya 75 responden yang bersedia mengisi kuesioner tersebut. Dari 75 responden, ada yang menjawab sudah pernah bekerja setelah lulus dari PS D-IV Akuntansi PNP sebanyak 54 orang (72\%) dan sisanya menjawab belum pernah bekerja sebanyak 21 orang (28\%).

\section{Analisis data}

Dalam melakukan analisis data digunakan uji beda. Peneliti menggunakan sign test dengan tingkat signifikansi 0,05 untuk melihat gap kompetensi alumni pada atribut keterampilan teknis dan TI. Selain itu, Mann-Whitney $U$ test dengan tingkat signifikansi 0,05 digunakan untuk melihat perbedaan kompetensi antara alumni tahun tamat 2019 dan 2020.

\section{Hasil dan Pembahasan}

\section{Karakteristik responden}

Responden yang mengisi sudah pernah bekerja setelah lulus dari PS D-IV Akuntansi PNP berjenis kelamin laki-laki sebanyak 31\% (17 orang) dan perempuan sebanyak $69 \%$ (37 orang). Jika dilihat dari tahun tamatnya, sebagian besar responden berasal dari alumni tahun 2019 sejumlah 34 dari 54 responden (63\%). Gambar 2 menunjukkan karakteristik responden berdasarkan nilai IPK. Responden dengan nilai IPK 3,50 - 3,75 berada pada posisi pertama sebesar 44\% dan dikuti oleh nilai IPK > 3,75 sebesar 30\%, dan nilai IPK 3,25 - 3,49 sebesar 20\%.

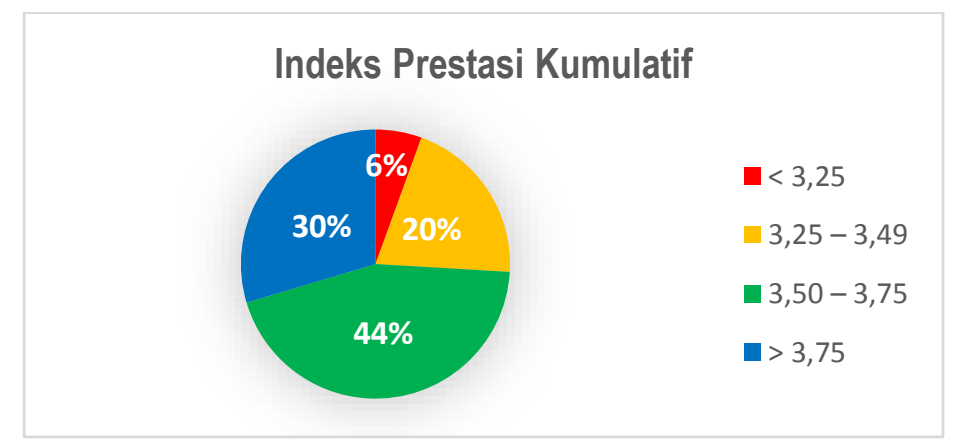

Gambar 2. Responden Berdasarkan IPK

Sumber : Olahan Data (2021) 
Gambar 3 menunjukkan pengelompokkan responden berdasarkan waktu tunggu. Sebagian besar waktu tunggu alumni untuk mendapatkan pekerjaan yaitu $<6$ bulan sebanyak 78\% sedangkan waktu tunggu yang relatif lebih lama yaitu $>6$ bulan sebanyak $22 \%$.

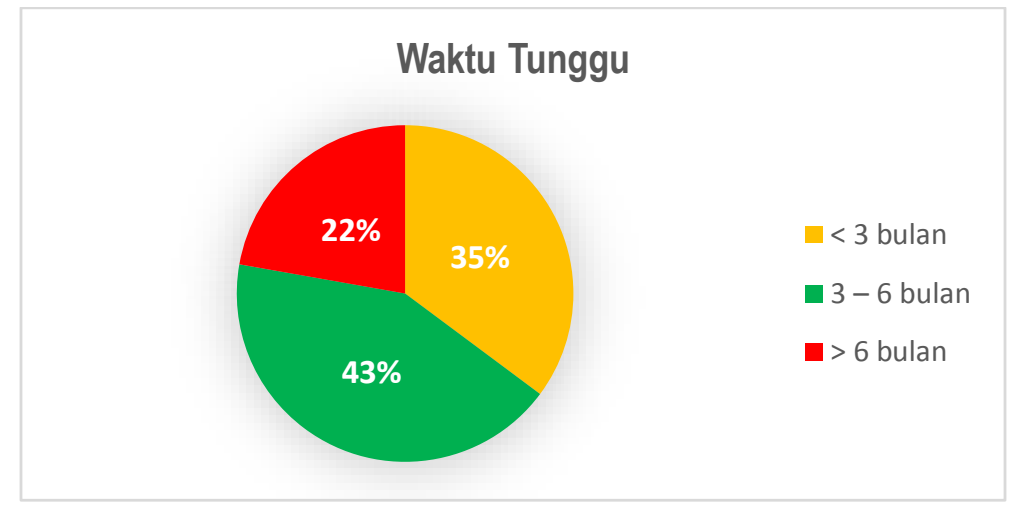

Gambar 3. Responden Berdasarkan Waktu Tunggu

Sumber : Olahan Data (2021)

Jika dilihat dari ukuran perusahaan, responden yang bekerja pertama kali pada perusahaan besar berada di posisi pertama dengan nilai 65\% (35 orang) dan diikuti oleh perusahaan menengah dengan nilai 24\% (13 orang) serta perusahaan kecil dengan nilai $11 \%$ (6 orang). Selain itu, gambar 4 menunjukkan pengelompokan responden dari pendapatan pada tahap entry level, sebagian besar responden memiliki pendapatan sesuai UMR (67\%) dan hanya sebagian kecil yang mendapatkan pendapatan sebesar 1,5 - 3 kali UMR.

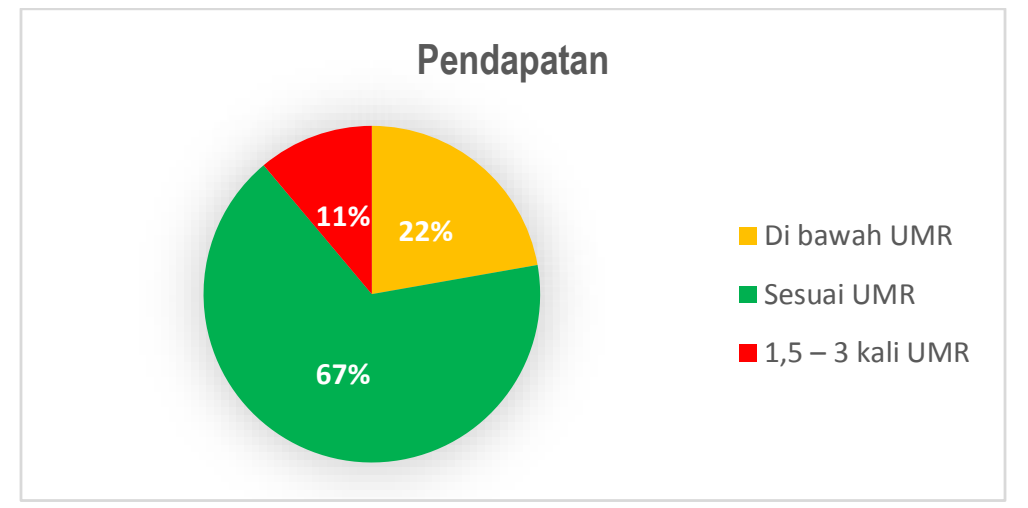

Gambar 4. Responden Berdasarkan Pendapatan

Sumber : Olahan Data (2021)

Berdasarkan tabel 1 di bawah ini, sebagian besar responden didominasi dengan jenis kelamin laki-laki yang bekerja pada perusahaan besar (76\%). Kebanyakan responden perempuan bekerja pada perusahaan besar dan menengah. Selain itu, responden yang tamat pada tahun 2019 dan 2020 setelah lulus sudah pernah bekerja di perusahaan besar bernilai sama yaitu 65\%. Responden yang memiliki nilai IPK 3,50 $-3,75$ sudah pernah bekerja pada perusahaan besar sebanyak $71 \%$ diikuti dengan nilai 
IPK > 3,75 sebanyak 69\%. Responden yang bekerja pada perusahaan menengah didominasi dengan nilai IPK 3,25 - 3,49 senilai 45\%.

Responden dengan waktu tunggu $>6$ bulan untuk mendapatkan pekerjaan pada perusahaan besar berada di posisi pertama (75\%) dan diikuti oleh responden dengan waktu tunggu $<3$ bulan (74\%). Selain itu, responden dengan waktu tunggu $3-6$ bulan kebanyakan bekerja pada perusahaan menengah. Jika dilihat dari pendapatan, sebagian besar responden mendapatkan pendapatan senilai 1,5 - 3 kali UMR pada perusahaan besar (100\%) diikuti oleh pendapatan sesuai UMR (64\%).

Tabel 1. Gambaran Umum Responden Berdasarkan Ukuran Perusahaan

\begin{tabular}{|c|c|c|c|c|c|c|c|c|}
\hline \multirow{3}{*}{ Keterangan } & \multicolumn{6}{|c|}{ Ukuran Perusahaan } & \multirow{2}{*}{\multicolumn{2}{|c|}{ Jumlah }} \\
\hline & \multicolumn{2}{|c|}{ Kecil } & \multicolumn{2}{|c|}{ Menengah } & \multicolumn{2}{|c|}{ Besar } & & \\
\hline & $\mathbf{F}$ & $\%$ & $\mathbf{F}$ & $\%$ & $\mathbf{F}$ & $\%$ & $\mathbf{F}$ & $\%$ \\
\hline \multicolumn{9}{|l|}{ Jenis Kelamin } \\
\hline Laki-Laki & 1 & 6 & 3 & 18 & 13 & 76 & 17 & 31 \\
\hline Perempuan & 5 & 14 & 10 & 27 & 22 & 59 & 37 & 69 \\
\hline \multicolumn{9}{|l|}{ Tahun Tamat } \\
\hline 2019 & 5 & 15 & 7 & 21 & 22 & 65 & 34 & 63 \\
\hline 2020 & 1 & 5 & 6 & 30 & 13 & 65 & 20 & 37 \\
\hline \multicolumn{9}{|l|}{ IPK } \\
\hline$<3,25$ & 0 & 0 & 1 & 33 & 2 & 67 & 3 & 6 \\
\hline $3,25-3,49$ & 1 & 9 & 5 & 45 & 5 & 45 & 11 & 20 \\
\hline $3,50-3,75$ & 2 & 8 & 5 & 21 & 17 & 71 & 24 & 44 \\
\hline$>3,75$ & 3 & 19 & 2 & 13 & 11 & 69 & 16 & 30 \\
\hline \multicolumn{9}{|l|}{$\begin{array}{l}\text { Waktu } \\
\text { tunggu }\end{array}$} \\
\hline$<3$ bulan & 1 & 5 & 4 & 21 & 14 & 74 & 19 & 35 \\
\hline $3-6$ bulan & 3 & 13 & 8 & 35 & 12 & 52 & 23 & 43 \\
\hline$>6$ bulan & 2 & 17 & 1 & 8 & 9 & 75 & 12 & 22 \\
\hline \multicolumn{9}{|l|}{ Pendapatan } \\
\hline Di bawah UMR & 3 & 25 & 3 & 25 & 6 & 50 & 12 & 22 \\
\hline Sesuai UMR & 3 & 8 & 10 & 28 & 23 & 64 & 36 & 67 \\
\hline $\begin{array}{c}\text { 1,5-3 kali } \\
\text { UMR }\end{array}$ & 0 & 0 & 0 & 0 & 6 & 100 & 6 & 11 \\
\hline \multicolumn{7}{|c|}{ Total Sampel } & 54 & 100 \\
\hline
\end{tabular}

Keterangan: $\mathrm{F}=$ Frekuensi

Sumber : Olahan Data (2021)

Pada tabel 2 menunjukkan pengelompokan responden secara rinci dari jenis kelamin, tahun tamat, IPK, dan waktu tunggu berdasarkan pendapatan. Sebagian besar responden baik perempuan maupun laki-laki mendapatkan pendapatan sesuai UMR masing-masing 70\% dan 59\%. Untuk pendapatan 1,5 - 3 kali UMR yang didapatkan oleh responden laki-laki lebih banyak dibandingkan responden perempuan senilai $24 \%$. 
Nilai IPK yang dimiliki responden ternyata tidak berpengaruh terhadap pendapatan yang didapat. Hal ini dapat dilihat bahwa responden dengan nilai IPK < 3,25 bisa mendapatkan pendapatan senilai 1,5 - 3 kali UMR (33\% merupakan persentase tertinggi dibandingkan IPK lainnya). Selain itu, responden dengan nilai IPK $>$ 3,75 bisa mendapatkan pendapatan dibawah UMR (13\%). Jadi, nilai IPK yang tinggi tidak menjamin untuk mendapatkan pendapatan diatas UMR dan pada pekerjaan pertama sebagian besar responden mendapatkan pendapatan sesuai UMR. Waktu tunggu juga tidak berpengaruh terhadap pendapatan. Sebagian besar responden mendapatkan pendapatan sesuai UMR baik waktu tunggunya $<6$ bulan maupun $>6$ bulan.

Tabel 2. Gambaran Umum Responden Berdasarkan Pendapatan

\begin{tabular}{|c|c|c|c|c|c|c|c|c|}
\hline \multirow{3}{*}{ Keterangan } & \multicolumn{6}{|c|}{ Pendapatan } & \multirow{2}{*}{\multicolumn{2}{|c|}{ Jumlah }} \\
\hline & \multicolumn{2}{|c|}{$\begin{array}{l}\text { Dibawah } \\
\text { UMR }\end{array}$} & \multicolumn{2}{|c|}{$\begin{array}{l}\text { Sesuai } \\
\text { UMR }\end{array}$} & \multicolumn{2}{|c|}{$\begin{array}{c}\text { 1,5 - } 3 \text { kali } \\
\text { UMR }\end{array}$} & & \\
\hline & $\mathbf{F}$ & $\%$ & $\mathbf{F}$ & $\%$ & $\mathbf{F}$ & $\%$ & $\mathbf{F}$ & $\%$ \\
\hline \multicolumn{9}{|l|}{ Jenis Kelamin } \\
\hline Laki-Laki & 3 & 18 & 10 & 59 & 4 & 24 & 17 & 31 \\
\hline Perempuan & 9 & 24 & 26 & 70 & 2 & 5 & 37 & 69 \\
\hline \multicolumn{9}{|l|}{ Tahun Tamat } \\
\hline 2019 & 5 & 15 & 25 & 74 & 4 & 12 & 34 & 63 \\
\hline 2020 & 7 & 35 & 11 & 55 & 2 & 10 & 20 & 37 \\
\hline \multicolumn{9}{|l|}{ IPK } \\
\hline$<3,25$ & 1 & 33 & 1 & 33 & 1 & 33 & 3 & 6 \\
\hline $3,25-3,49$ & 3 & 27 & 6 & 55 & 2 & 18 & 11 & 20 \\
\hline $3,50-3,75$ & 6 & 25 & 16 & 67 & 2 & 8 & 24 & 44 \\
\hline$>3,75$ & 2 & 13 & 13 & 81 & 1 & 6 & 16 & 30 \\
\hline \multicolumn{9}{|l|}{ Waktu tunggu } \\
\hline$<3$ bulan & 2 & 11 & 15 & 79 & 2 & 11 & 19 & 35 \\
\hline $3-6$ bulan & 8 & 35 & 13 & 57 & 2 & 9 & 23 & 43 \\
\hline$>6$ bulan & 2 & 17 & 8 & 67 & 2 & 17 & 12 & 22 \\
\hline \multicolumn{7}{|c|}{ Total Sampel } & 54 & 100 \\
\hline
\end{tabular}

Keterangan: $\mathrm{F}=$ Frekuensi

Sumber : Olahan Data (2021)

Tabel 3 menunjukkan pengelompokan responden secara rinci dari jenis kelamin, tahun tamat, dan IPK berdasarkan waktu tunggu. Sebagian besar, responden laki-laki dan perempuan memiliki waktu tunggu untuk mendapatkan pekerjaan sekitar $3-6$ bulan. Waktu tunggu responden yang tamat pada tahun 2019 relatif lebih singkat ( $<3$ bulan) dibandingkan tahun 2020. Responden dengan nilai IPK 3,50 - 3,75 memiliki waktu tunggu yang lebih singkat dibandingkan responden dengan nilai IPK lainnya. Jadi, dapat disimpulkan nilai IPK tidak terlalu berpengaruh dengan waktu tunggu sesuai dengan data yang didapatkan yaitu sebagian besar responden memiliki waktu tunggu 3 - 6 bulan. 
Tabel 3. Gambaran Umum Responden Berdasarkan Waktu Tunggu

\begin{tabular}{|c|c|c|c|c|c|c|c|c|}
\hline \multirow{3}{*}{ Keterangan } & \multicolumn{6}{|c|}{ Waktu Tunggu } & \multirow{2}{*}{\multicolumn{2}{|c|}{ Jumlah }} \\
\hline & \multicolumn{2}{|c|}{$<3$ bulan } & \multicolumn{2}{|c|}{$3-6$ bulan } & \multicolumn{2}{|c|}{$>6$ bulan } & & \\
\hline & $\mathbf{F}$ & $\%$ & $\mathbf{F}$ & $\%$ & $\mathbf{F}$ & $\%$ & $\mathbf{F}$ & $\%$ \\
\hline \multicolumn{9}{|l|}{ Jenis Kelamin } \\
\hline Laki-Laki & 6 & 35 & 8 & 47 & 3 & 18 & 17 & 31 \\
\hline Perempuan & 13 & 35 & 15 & 41 & 9 & 24 & 37 & 69 \\
\hline \multicolumn{9}{|l|}{ Tahun Tamat } \\
\hline 2019 & 13 & 38 & 10 & 29 & 11 & 32 & 34 & 63 \\
\hline 2020 & 6 & 30 & 13 & 65 & 1 & 5 & 20 & 37 \\
\hline \multicolumn{9}{|l|}{ IPK } \\
\hline$<3,25$ & 0 & 0 & 3 & 100 & 0 & 0 & 3 & 6 \\
\hline $3,25-3,49$ & 3 & 27 & 5 & 45 & 3 & 27 & 11 & 20 \\
\hline $3,50-3,75$ & 12 & 50 & 6 & 25 & 6 & 25 & 24 & 44 \\
\hline$>3,75$ & 4 & 25 & 9 & 56 & 3 & 19 & 16 & 30 \\
\hline \multicolumn{7}{|c|}{ Total Sampel } & 54 & 100 \\
\hline
\end{tabular}

Keterangan: $\mathrm{F}=$ Frekuensi

Sumber : Olahan Data (2021)

Jika dilihat dari posisi pekerjaan yang didapatkan saat pertama bekerja, sebagian besar responden bekerja sebagai staf keuangan/administrasi (37\%) dan auditor eksternal (35\%). Untuk posisi pekerjaan lainnya tidak begitu dominan dan tidak mencapai nilai 10\%. Untuk lebih rincinya dapat dilihat pada tabel 4 berikut.

Tabel 4. Posisi Pekerjaan Pertama Kali

\begin{tabular}{|l|r|r|}
\hline \multicolumn{1}{|c|}{ Pekerjaan } & $\begin{array}{c}\text { Frekuensi } \\
\text { (F) }\end{array}$ & Persentase \\
\hline Staf keuangan/administrasi & 20 & $37 \%$ \\
\hline Auditor eksternal & 19 & $35 \%$ \\
\hline Auditor internal & 3 & $6 \%$ \\
\hline $\begin{array}{l}\text { Staff lembaga } \\
\text { keuangan/pembiayaan (contoh: } \\
\text { Bank, Pegadaian) }\end{array}$ & 3 & $6 \%$ \\
\hline Admin account & & 2 \\
\hline Akuntan manajemen & 1 & $2 \%$ \\
\hline Staff perpajakan & 1 & $2 \%$ \\
\hline Admin pajak \& tax litigation & 1 & $2 \%$ \\
\hline Bendahara Total & 1 & $2 \%$ \\
\hline Asisten Ketua Jurusan & 1 & $2 \%$ \\
\hline Teller Sumber : Olahan & 1 & $2 \%$ \\
\hline Quality control & 1 & $2 \%$ \\
\hline \multicolumn{1}{|c|}{ The } & $\mathbf{5 4}$ & $\mathbf{1 0 0 \%}$ \\
\hline
\end{tabular}

Sumber : Olahan Data (2021) 
Lokasi instansi/organisasi tempat bekerja pertama kali responden sebagian besar berada di DKI Jakarta dan diikuti oleh Padang, Sumatera Barat. Untuk lebih detailnya, dapat dilihat pada tabel 5 .

Tabel 5. Lokasi Instansi/Organisasi

\begin{tabular}{|c|c|c|}
\hline Lokasi & $\begin{array}{l}\text { Frekuensi } \\
\text { (F) }\end{array}$ & Persentase \\
\hline Agam, Sumatera Barat & 2 & $4 \%$ \\
\hline Batam, Kepulauan Riau & 2 & $4 \%$ \\
\hline $\begin{array}{l}\text { Bukittinggi, Sumatera } \\
\text { Barat }\end{array}$ & 3 & $6 \%$ \\
\hline $\begin{array}{l}\text { Deli Serdang, Sumatera } \\
\text { Utara }\end{array}$ & 1 & $2 \%$ \\
\hline Denpasar, Bali & 1 & $2 \%$ \\
\hline Depok, Jawa Barat & 1 & $2 \%$ \\
\hline $\begin{array}{l}\text { Dharmasraya, Sumatera } \\
\text { Barat }\end{array}$ & 1 & $2 \%$ \\
\hline DKI Jakarta & 21 & $39 \%$ \\
\hline Jawa Barat & 1 & $2 \%$ \\
\hline Kab. Bekasi, Jawa Barat & 1 & $2 \%$ \\
\hline Padang, Sumatera Barat & 11 & $20 \%$ \\
\hline Pasaman, Sumatera Barat & 3 & $6 \%$ \\
\hline $\begin{array}{l}\text { Payakumbuh, Sumatera } \\
\text { Barat }\end{array}$ & 1 & $2 \%$ \\
\hline Pekanbaru, Riau & 2 & $4 \%$ \\
\hline $\begin{array}{l}\text { Sawahlunto, Sumatera } \\
\text { Barat }\end{array}$ & 1 & $2 \%$ \\
\hline Siak, Riau & 1 & $2 \%$ \\
\hline Sibolga, Sumatera Utara & 1 & $2 \%$ \\
\hline Total & 54 & $100 \%$ \\
\hline
\end{tabular}

Sumber : Olahan Data (2021)

Untuk posisi saat ini, sebagian besar responden sebanyak 34 orang (63\%) menjawab "Ya" masih bekerja pada instansi/organisasi pertama kali. Namun, adanya responden sebanyak 20 orang (37\%) sudah berhenti bekerja pada instansi/organisasi tersebut dengan berbagai alasan. Alasan-alasannya meliputi mendapatkan tawaran pekerjaan lain (25\%), telah berakhirnya masa kontrak (15\%), hubungan kerja yang tidak sehat (15\%), gaji yang tidak memadai $(10 \%)$, ingin mendapatkan pekerjaan sebagai ASN (10\%), ingin mendapatkan pengalaman baru (10\%), pekerjaan tidak sesuai dengan kompetensi (5\%), jenjang karir yang kurang jelas (5\%), ataupun kebijakan perusahaan untuk mengurangi jumlah karyawan karena dampak pandemi Covid-19 (5\%). Jangka waktu bekerja pada instansi/organisasi pertama sebelum pindah kerja pun beragam. Sebagian besar jangka waktu bekerja pada instansi/organisasi sebelum pindah kerja yaitu $3-6$ bulan sebesar 60\% (12 orang) diikuti jangka waktu $<3$ bulan sebesar 35\% (7 orang) dan $>6$ bulan sebesar $5 \%$ ( 1 orang). 


\section{Persebaran Jawaban Responden}

Jika dilihat dari persebaran jawaban responden per masing-masing keterampilan sangat beragam. Pada bagian ini, responden diminta untuk menilai keterampilan teknis dan TI-nya dengan pilihan kurang, cukup, sesuai, dan melebihi. Sebagian besar responden (dengan nilai IPK yang berbeda-beda) menjawab memiliki tingkat keterampilan yang sesuai dengan tuntutan pekerjaan pertama mereka. Tingkat kesesuaian keterampilan teknis paling tinggi yaitu keterampilan dalam menyajikan laporan keuangan (72\%), merencanakan dan melaksanakan audit (68\%), serta melakukan pengendalian internal (66\%). Hal ini mengingat sebagian besar pekerjaan pertama responden sebagai auditor eksternal dan staf keuangan/administrasi seperti yang telah dijelaskan pada tabel 4. Tingkat kesesuaian keterampilan teknis yang paling rendah meliputi keterampilan mengonsolidasikan laporan keuangan (48\%), mempersiapkan administrasi perpajakan (43\%), dan memahami Akuntansi Syariah (37\%). Untuk informasi lainnya, dapat dilihat pada gambar 5.

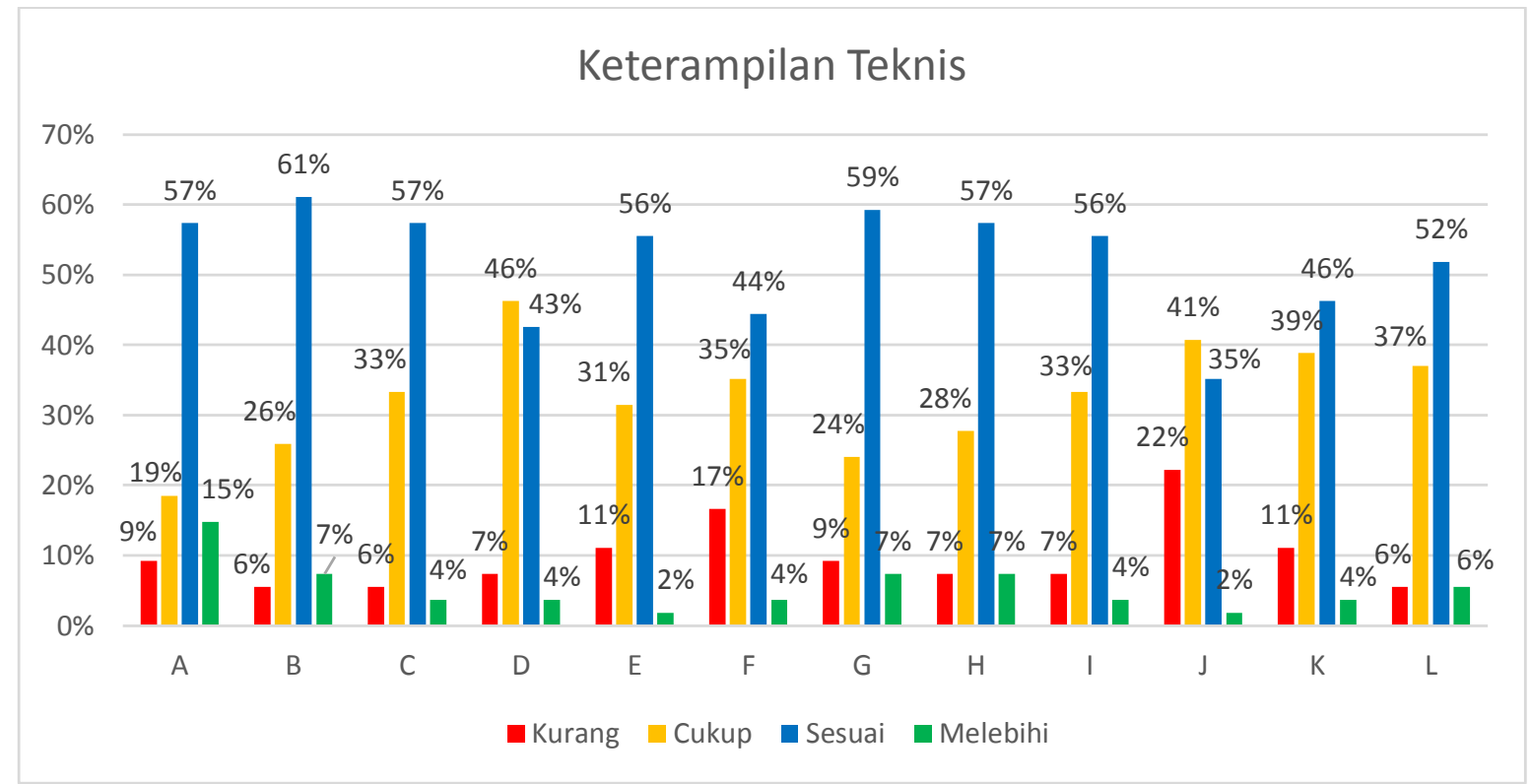

Gambar 5. Persebaran Jawaban Responden Pada Pertanyaan Keterampilan Teknis

Sumber : Olahan Data (2021)

Keterangan: $A=$ Menyajikan laporan keuangan; $B=$ Merencanakan dan melakukan audit; $\mathrm{C}=$ Menganalisis biaya dan margin; $\mathrm{D}=$ Mempersiapkan administrasi perpajakan; $\mathrm{E}=$ Mengelola sumber dan penggunaan dana di perusahaan; $\mathrm{F}=$ Mengonsolidasikan laporan keuangan; $\mathrm{G}=$ Melakukan pengendalian internal; $\mathrm{H}=$ Menghitung kinerja perusahaan; I=Merencanakan dan mempersiapkan anggaran; J=Memahami Akuntansi Syariah; K=Memahami Akuntansi Sektor Publik; L=Menggunakan metode kuantitatif untuk analisis data.

Selain itu, adanya keberagaman jawaban responden terhadap tingkat keterampilan teknologi informasi (TI). Sebagian besar responden (dengan nilai IPK yang berbeda-beda) merasa tingkat keterampilan TI sesuai dengan tuntutan pekerjaan pertama mereka. Tingkat kesesuaian keterampilan yang paling tinggi yaitu menggunakan Microsoft Office (91\%), menggunakan media sosial (78\%), 
menggunakan software Akuntansi (63\%), serta menyajikan informasi dalam bentuk teks dan visual grafis (57\%). Selain itu, sebagian besar responden merasa keterampilan menggunakan software analisis data mereka bernilai cukup (57\%). Secara garis besar, tingkat keterampilan TI responden sangat baik dilihat dari persepsinya terhadap semua atribut keterampilan TI. Untuk informasi lainnya dapat dilihat pada gambar 6.

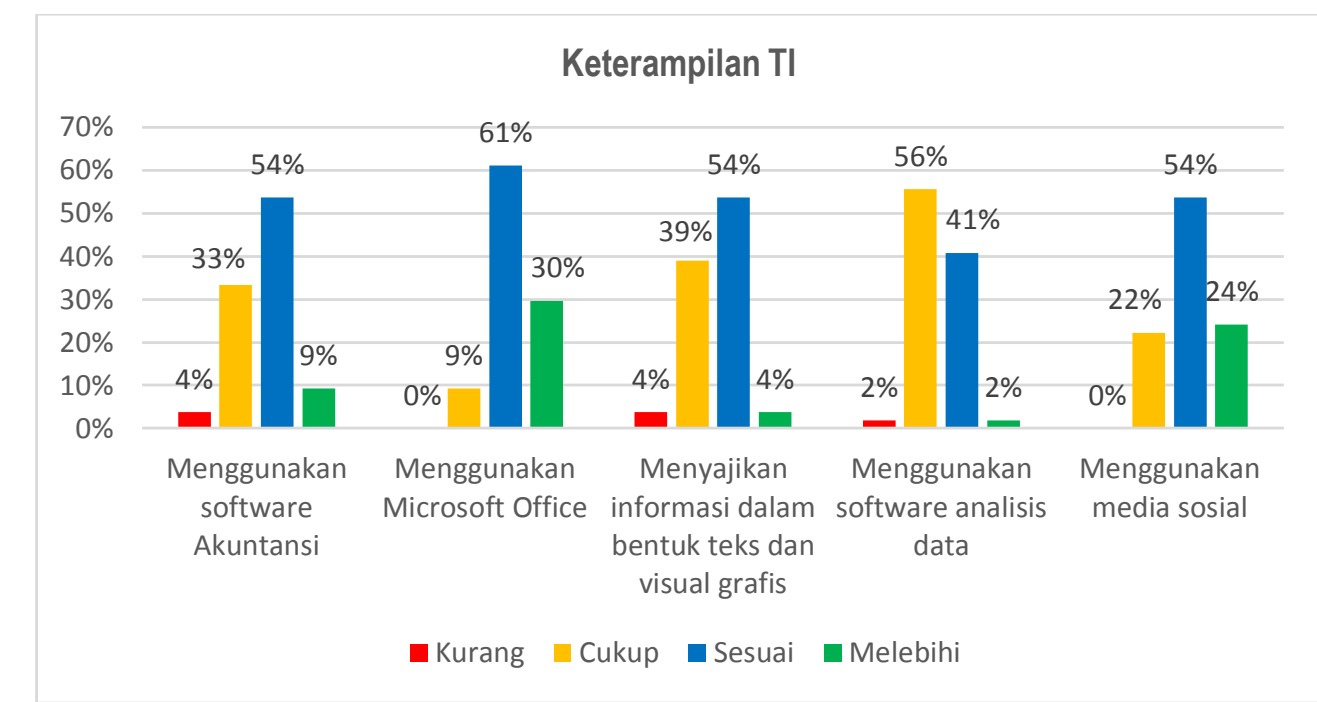

Gambar 6. Persebaran Jawaban Responden Pada Pertanyaan Keterampilan TI

Sumber : Olahan Data (2021)

Selanjutnya, responden diminta untuk merangking kelima atribut keterampilan interpersonal berdasarkan keterampilan yang perlu ditingkatkan selama pekerjaan pertama. Keterampilan kepemimpinan, kerja tim dan mendengarkan pendapat orang lain sangat perlu ditingkatkan pada pekerjaan pertama. Hal ini sesuai dengan hasil penelitian yang dilakukan oleh Kavanagh \& Drennan (2008), Jackling \& De Lange (2009) dan Tempone et al. (2012), pentingnya untuk meningkatkan keterampilan interpersonal. Selain itu, kejujuran berada di posisi terakhir dalam perangkingan keterampilan yang perlu ditingkat berdasarkan pengalaman pada pekerjaan pertama. Hal ini terjadi karena saat kuliah pada Program Studi Diploma IV Akuntansi Politeknik Negeri Padang, mahasiswa sudah diajarkan pentingnya menjunjung tinggi kejujuran. Untuk informasi lainnya dapat dilihat pada gambar 7. 


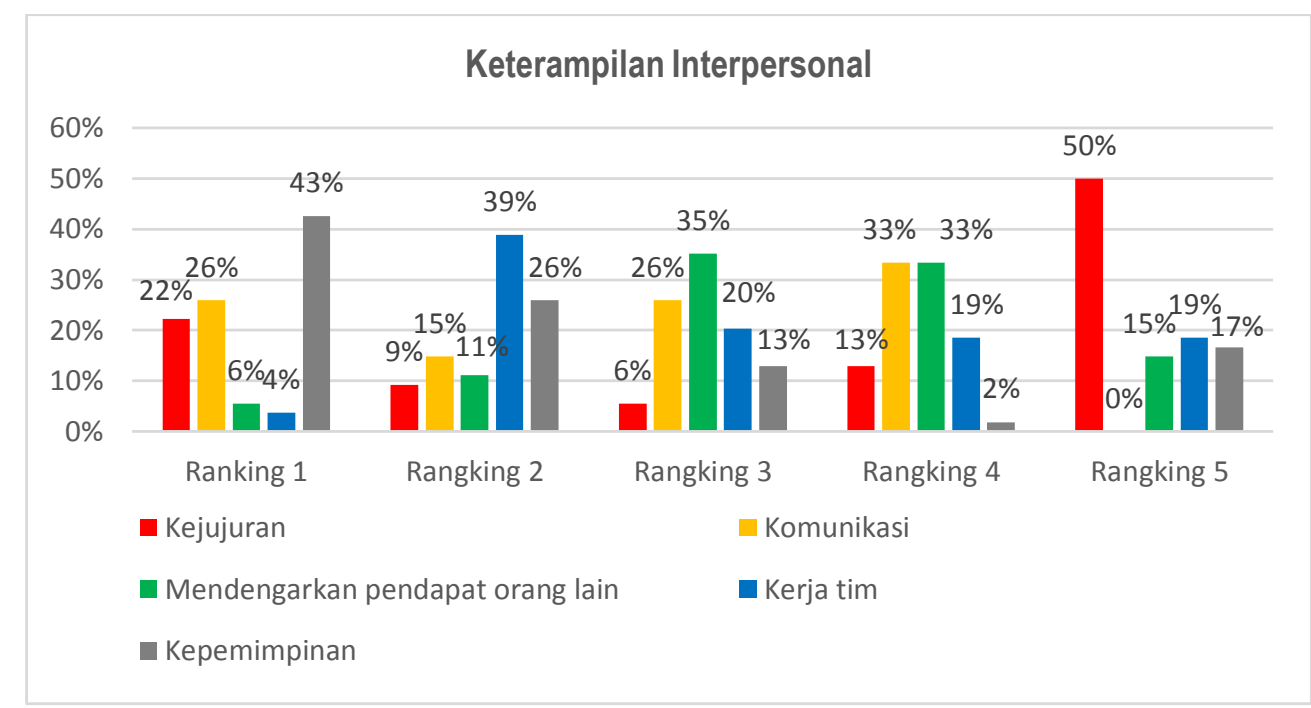

Gambar 7. Persebaran Jawaban Responden Pada Pertanyaan Keterampilan Interpersonal

Sumber : Olahan Data (2021)

Gambar 8 menunjukkan keterampilan personal dalam bekerja yang perlu ditingkatkan yaitu keterampilan memprioritaskan pekerjaan, memecahkan masalah dan memiliki perspektif yang berbeda dalam melihat suatu hal. Namun, keterampilan memprioritaskan pekerjaan juga berada di posisi kelima dengan persentase $7 \%$ lebih tinggi dibandingkan pada posisi pertama sebelumnya. Hasil penelitian sejalan dengan penelitian yang dilakukan oleh Tempone et al. (2012) dan Klibi \& Oussii (2013) yaitu pentingnya untuk meningkatkan keterampilan personal dalam bekerja. Jadi, dapat dikatakan setiap orang memiliki tingkat keterampilan manajemen yang berbeda-beda.

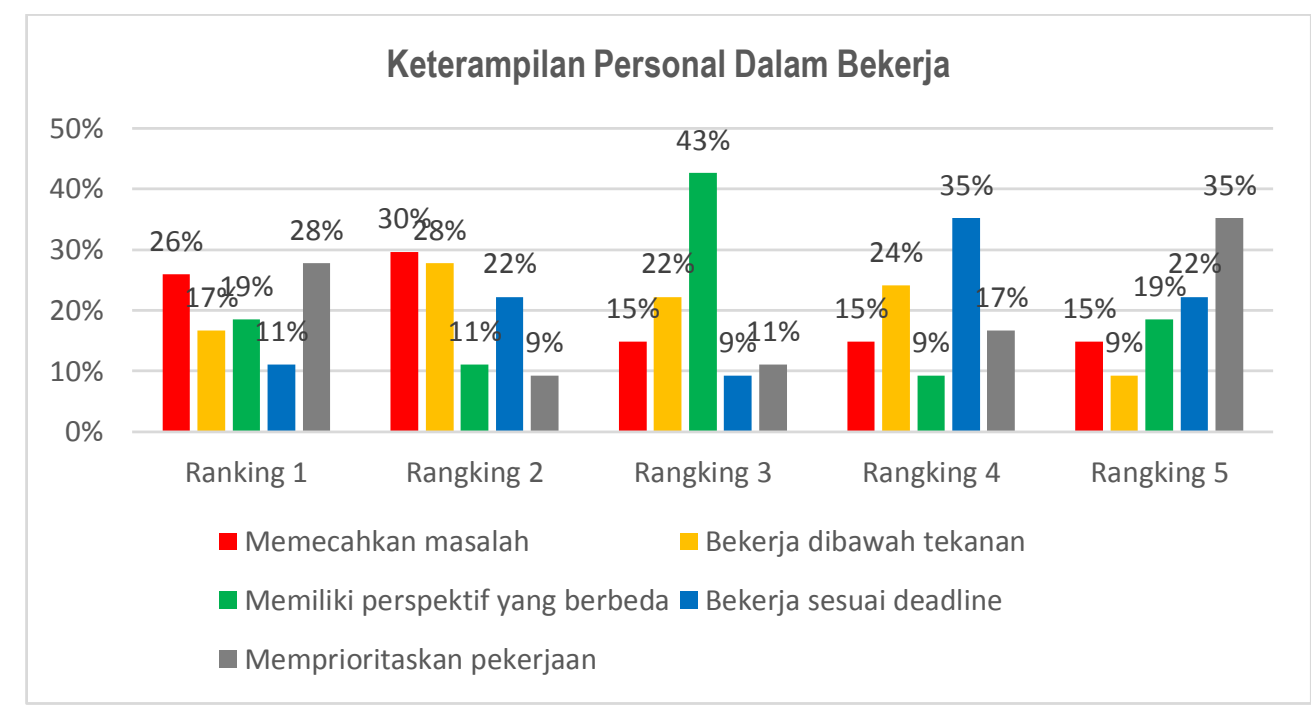

Gambar 8. Persebaran Jawaban Responden Pada Pertanyaan Keterampilan Personal Dalam Bekerja

Sumber : Olahan Data (2021) 
Responden diminta untuk merangking keempat keterampilan personal dalam mengembangkan diri berdasarkan keterampilan yang perlu ditingkatkan selama pekerjaan pertama. Berdasarkan jawaban responden pada gambar 9, keterampilan yang perlu ditingkatkan yaitu keterampilan melihat potensi diri, kemampuan dalam mencapai tujuan yang telah ditetapkan serta pembelajaran berkelanjutan. Namun, untuk keterampilan berempati berada di posisi keempat. Hal ini berarti responden memiliki tingkat empati yang lebih baik. Hasil penelitian ini sesuai dengan penelitian yang dilakukan oleh Bui \& Porter (2010) bahwa pemberi kerja membutuhkan lulusan Akuntansi yang menunjukkan potensi untuk pembelajaran berkelanjutan.

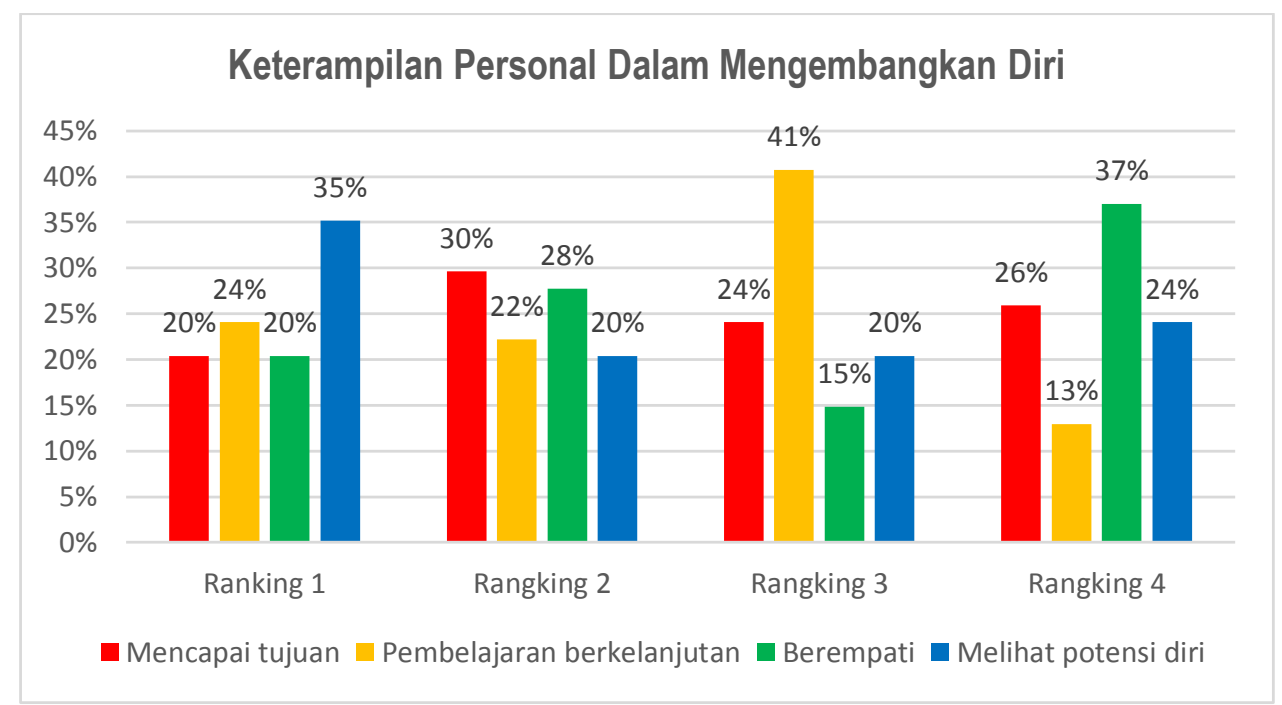

Gambar 9. Persebaran Jawaban Responden Pada Pertanyaan Keterampilan Dalam Mengembangkan Diri

Sumber : Olahan Data (2021)

\section{Sign test}

Uji tanda (sign test) dilakukan pada keterampilan teknis dan teknologi informasi dengan bantuan aplikasi Minitab versi 19.1. $\mathrm{H} 1_{0}$ diasumsikan terdapat gap kompetensi yang dihadapi oleh alumni PS D-IV Akuntansi PNP sehingga ditulis H10: $\eta=2,99$. H11 diasumsikan tidak terdapat gap kompetensi yang dihadapi oleh alumni PS D-IV Akuntansi PNP sehingga ditulis H11: $\eta>2$,99. Uji hipotesis dilakukan untuk masingmasing atribut keterampilan. Dasar pengambilan keputusan berdasarkan hasil $p$-value yang didapatkan. Apabila $p$-value $\geq 0,05$ maka $\mathrm{H}_{0}$ diterima dan sebaliknya jika $p$-value $<0,05$ maka $\mathrm{H}_{0}$ ditolak.

Pada tabel 6 menunjukkan bahwa terdapat gap kompetensi yang dihadapi oleh alumni PS D-IV Akuntansi PNP pada keterampilan menganalisis biaya dan margin, mempersiapkan administrasi perpajakan, mengelola sumber dan penggunaan dana di perusahaan, mengonsolidasikan laporan keuangan, merencanakan dan mempersiapkan anggaran, memahami Akuntansi Syariah, memahami Akuntansi Sektor Publik, dan menggunakan metode kuantitatif untuk analisis data. Hal ini dikarenakan $p$-value pada atribut keterampilan teknis tersebut bernilai $>0,05$ sehingga $\mathrm{H}_{0}$ diterima. Untuk keterampilan teknis lainnya seperti menyajikan laporan keuangan, merencanakan dan melakukan audit, melakukan pengendalian internal, dan 
menghitung kinerja perusahaan tidak terdapat gap kompetensi karena $p$-value yang didapatkan < 0,05 berarti $\mathrm{H}_{0}$ ditolak. Jika nilai $p$-value pada atribut keterampilan teknis diurut berdasarkan nilai yang tertinggi maka hasilnya sama dengan penjelasan persebaran jawaban responden pada gambar 5 .

Tabel 6. Uji Tanda Keterampilan Teknis

\begin{tabular}{|c|c|c|c|c|c|c|}
\hline $\begin{array}{c}\text { Atribut Keterampilan } \\
\text { Teknis }\end{array}$ & $\begin{array}{l}N< \\
2,99\end{array}$ & $\begin{array}{l}N= \\
2,99\end{array}$ & $\begin{array}{l}N> \\
2,99\end{array}$ & $\begin{array}{c}p- \\
\text { value }\end{array}$ & $\alpha$ & Keterangan \\
\hline $\begin{array}{l}\text { Menyajikan laporan } \\
\text { keuangan }\left(\mathrm{KTE}_{1}\right)\end{array}$ & 15 & 0 & 39 & 0,001 & 0,05 & $\mathrm{H}_{0}$ Ditolak \\
\hline $\begin{array}{lr}\text { Merencanakan } & \text { dan } \\
\text { melakukan audit } & \left(\mathrm{KTE}_{2}\right)\end{array}$ & 17 & 0 & 37 & 0,005 & 0,05 & $\mathrm{H}_{0}$ Ditolak \\
\hline $\begin{array}{l}\text { Menganalisis biaya dan } \\
\text { margin }\left(\mathrm{KTE}_{3}\right)\end{array}$ & 21 & 0 & 33 & 0,067 & 0,05 & $\mathrm{H}_{0}$ Diterima \\
\hline $\begin{array}{l}\text { Mempersiapkan } \\
\text { administrasi } \\
\text { perpajakan (KTE4) }\end{array}$ & 29 & 0 & 25 & 0,752 & 0,05 & $\mathrm{H}_{0}$ Diterima \\
\hline $\begin{array}{l}\text { Mengelola sumber dan } \\
\text { penggunaan dana di } \\
\text { perusahaan }\left(\mathrm{KTE}_{5}\right)\end{array}$ & 23 & 0 & 31 & 0,170 & 0,05 & $\mathrm{H}_{0}$ Diterima \\
\hline $\begin{array}{l}\text { Mengonsolidasikan } \\
\text { laporan } \\
\text { (KTE6) }\end{array}$ & 28 & 0 & 26 & 0,658 & 0,05 & $\mathrm{H}_{0}$ Diterima \\
\hline $\begin{array}{l}\text { Melakukan } \\
\text { pengendalian internal } \\
\left(\mathrm{KTE}_{7}\right)\end{array}$ & 18 & 0 & 36 & 0,010 & 0,05 & $\mathrm{H}_{0}$ Ditolak \\
\hline $\begin{array}{l}\text { Menghitung kinerja } \\
\text { perusahaan }\left(\mathrm{KTE}_{8}\right)\end{array}$ & 19 & 0 & 35 & 0,021 & 0,05 & $\mathrm{H}_{0}$ Ditolak \\
\hline $\begin{array}{l}\text { Merencanakan dan } \\
\text { mempersiapkan } \\
\text { anggaran (KTE9) }\end{array}$ & 22 & 0 & 32 & 0,110 & 0,05 & $\mathrm{H}_{0}$ Diterima \\
\hline $\begin{array}{l}\text { Memahami Akuntansi } \\
\text { Syariah }\left(\mathrm{KTE}_{10}\right)\end{array}$ & 34 & 0 & 20 & 0,979 & 0,05 & $\mathrm{H}_{0}$ Diterima \\
\hline $\begin{array}{l}\text { Memahami Akuntansi } \\
\text { Sektor Publik (KTE } 11)\end{array}$ & 27 & 0 & 27 & 0,554 & 0,05 & $\mathrm{H}_{0}$ Diterima \\
\hline $\begin{array}{l}\text { Menggunakan metode } \\
\text { kuantitatif } \\
\text { analisis data }\left(\mathrm{KTE}_{12}\right)\end{array}$ & 23 & 0 & 31 & 0,170 & 0,05 & $\mathrm{H}_{0}$ Diterima \\
\hline
\end{tabular}

Sumber : Olahan Data (2021)

Tabel 7 menunjukkan bahwa terdapat gap kompetensi yang dihadapi oleh alumni PS D-IV Akuntansi PNP pada atribut keterampilan TI meliputi menyajikan informasi dalam bentuk teks dan visual grafis dan menggunakan software analisis data. Hal ini dikarenakan $p$-value yang didapatkan $>0,05$ sehingga $\mathrm{H}_{0}$ diterima. Selain itu, atribut keterampilan menggunakan software Akuntansi, menggunakan Microsoft Office, dan menggunakan media sosial tidak terdapat gap karena nilai $p$-value yang 
didapatkan $<0,05$. Jika nilai $p$-value pada atribut keterampilan TI diurut berdasarkan nilai yang tertinggi maka hasilnya sama dengan penjelasan persebaran jawaban responden pada gambar 6 sebelumnya.

Tabel 7. Uji Tanda Keterampilan Teknologi Informasi

\begin{tabular}{|c|c|c|c|c|c|c|}
\hline $\begin{array}{c}\text { Atribut Keterampilan } \\
\text { Teknologi Informasi }\end{array}$ & $\mathbf{N}<3$ & $\mathbf{N}=3$ & $\mathrm{~N}>3$ & $p$-value & $\alpha$ & Keterangan \\
\hline $\begin{array}{ll}\text { Menggunakan } & \text { software } \\
\text { Akuntansi (KTI } 1) & \\
\end{array}$ & 20 & 0 & 34 & 0,038 & 0,05 & $\mathrm{H}_{0}$ Ditolak \\
\hline $\begin{array}{ll}\text { Menggunakan } & \text { Microsoft } \\
\text { Office }\left(\mathrm{KTI}_{2}\right) & \end{array}$ & 5 & 0 & 49 & 0,001 & 0,05 & $\mathrm{H}_{0}$ Ditolak \\
\hline $\begin{array}{l}\text { Menyajikan informasi dalam } \\
\text { bentuk teks dan visual grafis } \\
\left(\mathrm{KTI}_{3}\right)\end{array}$ & 23 & 0 & 31 & 0,170 & 0,05 & $\begin{array}{c}\mathrm{H}_{0} \\
\text { Diterima }\end{array}$ \\
\hline $\begin{array}{l}\text { Menggunakan software } \\
\text { analisis data }\left(\mathrm{KTI}_{4}\right)\end{array}$ & 31 & 0 & 23 & 0,890 & 0,05 & $\begin{array}{c}\mathrm{H}_{0} \\
\text { Diterima }\end{array}$ \\
\hline $\begin{array}{l}\text { Menggunakan media sosial } \\
\text { (KTI5) }\end{array}$ & 12 & 0 & 42 & 0,001 & 0,05 & $\mathrm{H}_{0}$ Ditolak \\
\hline
\end{tabular}

Sumber : Olahan Data (2021)

\section{Mann-whitney U test}

Uji Mann-Whitney U dilakukan pada keterampilan teknis dan teknologi informasi dengan bantuan aplikasi SPSS versi 21 . $\mathrm{H} 2{ }_{0}$ diasumsikan tidak terdapat perbedaan kompetensi antara alumni PS D-IV Akuntansi PNP tahun tamat 2019 dan 2020 ditulis H20: $\mathrm{U}_{2019}=\mathrm{U}_{2020}$. H2 1 diasumsikan terdapat perbedaan kompetensi antara alumni PS D-IV Akuntansi PNP tahun tamat 2019 dan 2020 ditulis H2 : U $_{2019} \neq \mathrm{U}_{2020}$. Dasar pengambilan keputusan berdasarkan nilai signifikansi. Apabila nilai signifikansi $\geq 0,05$ maka $\mathrm{H} 0$ diterima dan sebaliknya jika nilai signifikansi $<0,05$ maka terdapat $\mathrm{H}_{0}$ ditolak.

Tabel 8 menunjukkan bahwa seluruh $\mathrm{H}_{0}$ pada atribut keterampilan teknis diterima. Hal ini dikarenakan nilai signifikansi yang didapatkan $>0,05$. Jadi, dapat disimpulkan tidak terdapat perbedaan kompetensi antara alumni Program Studi Diploma IV Akuntansi Politeknik Negeri Padang tahun tamat 2019 dan 2020 pada keterampilan teknisnya.

Tabel 8. Uji Mann-Whitney U Keterampilan Teknis

\begin{tabular}{|l|c|c|c|c|}
\hline \multicolumn{1}{|c|}{ Atribut Keterampilan Teknis } & $\begin{array}{c}\text { Mann- } \\
\text { Whitney }\end{array}$ & $\begin{array}{c}\text { Nilai } \\
\text { signifikansi }\end{array}$ & $\boldsymbol{\alpha}$ & Keterangan \\
\hline $\begin{array}{l}\text { Menyajikan laporan keuangan } \\
\text { (KTE })\end{array}$ & 310 & 0,548 & 0,05 & $\mathrm{H}_{0}$ Diterima \\
\hline $\begin{array}{l}\text { Merencanakan dan melakukan } \\
\text { audit (KTE2) }\end{array}$ & 292 & 0,322 & 0,05 & $\mathrm{H}_{0}$ Diterima \\
\hline $\begin{array}{l}\text { Menganalisis biaya dan margin } \\
\text { (KTE } 3 \text { ) }\end{array}$ & 321,5 & 0,706 & 0,05 & $\mathrm{H}_{0}$ Diterima \\
\hline $\begin{array}{l}\text { Mempersiapkan administrasi } \\
\text { perpajakan (KTE4) }\end{array}$ & 331,5 & 0,867 & 0,05 & $\mathrm{H}_{0}$ Diterima \\
\hline
\end{tabular}




\begin{tabular}{|l|c|c|c|c|}
\hline \multicolumn{1}{|c|}{ Atribut Keterampilan Teknis } & $\begin{array}{c}\text { Mann- } \\
\text { Whitney }\end{array}$ & $\begin{array}{c}\text { Nilai } \\
\text { signifikansi }\end{array}$ & $\boldsymbol{\alpha}$ & Keterangan \\
\hline $\begin{array}{l}\text { Mengelola sumber dan } \\
\text { penggunaan dana di perusahaan } \\
\text { (KTE5) }\end{array}$ & 302 & 0,446 & 0,05 & $\mathrm{H}_{0}$ Diterima \\
\hline $\begin{array}{l}\text { Mengonsolidasikan laporan } \\
\text { keuangan (KTE6) }\end{array}$ & 293,5 & 0,370 & 0,05 & $\mathrm{H}_{0}$ Diterima \\
\hline $\begin{array}{l}\text { Melakukan pengendalian internal } \\
\text { (KTE7) }\end{array}$ & 336 & 0,935 & 0,05 & $\mathrm{H}_{0}$ Diterima \\
\hline $\begin{array}{l}\text { Menghitung kinerja perusahaan } \\
\text { (KTE8) }\end{array}$ & 296,5 & 0,380 & 0,05 & $\mathrm{H}_{0}$ Diterima \\
\hline $\begin{array}{l}\text { Merencanakan dan } \\
\text { mempersiapkan anggaran (KTE9) }\end{array}$ & 313 & 0,587 & 0,05 & $\mathrm{H}_{0}$ Diterima \\
\hline $\begin{array}{l}\text { Memahami Akuntansi Syariah } \\
\text { (KTE10) }\end{array}$ & 281 & 0,259 & 0,05 & $\mathrm{H}_{0}$ Diterima \\
\hline $\begin{array}{l}\text { Memahami Akuntansi Sektor } \\
\text { Publik (KTE11) }\end{array}$ & 337,5 & 0,961 & 0,05 & $\mathrm{H}_{0}$ Diterima \\
\hline $\begin{array}{l}\text { Menggunakan metode kuantitatif } \\
\text { untuk analisis data (KTE12) }\end{array}$ & 328 & 0,811 & 0,05 & $\mathrm{H}_{0}$ Diterima \\
\hline
\end{tabular}

Sumber : Olahan Data (2021)

Tabel 9 menunjukkan bahwa seluruh $\mathrm{H}_{0}$ pada atribut keterampilan TI diterima. Hal ini dikarenakan nilai signifikansi yang didapatkan $>0,05$. Jadi, dapat disimpulkan tidak terdapat perbedaan kompetensi antara alumni PS D-IV Akuntansi PNP tahun tamat 2019 dan 2020 pada keterampilan TI-nya.

Tabel 9. Uji Mann-Whitney U Keterampilan Teknologi Informasi

\begin{tabular}{|c|c|c|c|c|}
\hline $\begin{array}{l}\text { Atribut Keterampilan Teknologi } \\
\text { Informasi }\end{array}$ & $\begin{array}{c}\text { Mann- } \\
\text { Whitney }\end{array}$ & $\begin{array}{c}\text { Nilai } \\
\text { signifikansi }\end{array}$ & $\alpha$ & Keterangan \\
\hline $\begin{array}{l}\text { Menggunakan software Akuntansi } \\
\left(\mathrm{KTI}_{1}\right)\end{array}$ & 319 & 0,676 & 0,05 & $\mathrm{H}_{0}$ Diterima \\
\hline $\begin{array}{l}\text { Menggunakan Microsoft Office } \\
\left(\mathrm{KTI}_{2}\right)\end{array}$ & 333,5 & 0,893 & 0,05 & $\mathrm{H}_{0}$ Diterima \\
\hline $\begin{array}{lll}\text { Menyajikan } & \text { informasi } & \text { dalam } \\
\text { bentuk teks dan visual grafis } \\
\left(\mathrm{KTI}_{3}\right)\end{array}$ & 315,5 & 0,621 & 0,05 & $\mathrm{H}_{0}$ Diterima \\
\hline $\begin{array}{l}\text { Menggunakan software analisis } \\
\text { data }\left(\mathrm{KTI}_{4}\right)\end{array}$ & 276 & 0,189 & 0,05 & $\mathrm{H}_{0}$ Diterima \\
\hline Menggunakan media sosial (KTI 5 ) & 332,5 & 0,882 & 0,05 & $\mathrm{H}_{0}$ Diterima \\
\hline
\end{tabular}

Sumber : Olahan Data (2021)

\section{Simpulan dan Saran}

Penelitian ini bertujuan untuk menguji apakah terdapat gap kompetensi yang dihadapi oleh alumni PS D-IV Akuntansi PNP pada pekerjaan pertama. Hasil penelitian ini sesuai dengan teori kontingensi tindakan dan kinerja yang diperkenalkan oleh Boyatzis yaitu kinerja maksimal terjadi apabila kapabilitas individu sesuai dengan tuntutan 
pekerjaan dan lingkungan organisasi. Hasil penelitian ini juga sejalan dengan penelitian yang dilakukan oleh Kavanagh dan Drennan (2008), Jackling De Lange (2009) dan Low et al. (2016) dalam bekerja pada bidang Akuntansi dibutuhkan keterampilan teknis Akuntansi. Keterampilan teknis yang diajarkan pada PS D-IV Akuntansi PNP sangat relevan dengan kebutuhan dunia kerja. Hal ini dikarenakan sistem pembelajarannya yang didesain secara aplikatif. Namun, gap kompetensi pada keterampilan teknis terjadi karena adanya perbedaan kebutuhan antara satu pekerjaan dengan pekerjaan lainnya. Selain itu, hasil penelitian ini sesuai dengan hasil penelitian Tempone et al. (2012), Abayadeera dan Watty (2014) dan Low et al. (2016), untuk meningkatkan keterampilan generik yang diperlukan demi kesuksesan karier di bidang Akuntansi [16], [1], [11]. Berdasarkan hasil penelitian ini maka dapat disimpulkan hal-hal berikut ini:

1) Terdapat gap kompetensi yang dihadapi oleh alumni PS D-IV Akuntansi PNP pada atribut keterampilan teknis dan teknologi informasi kecuali dalam menyajikan laporan keuangan, merencanakan dan melakukan audit, melakukan pengendalian internal, menghitung kinerja perusahaan, serta menggunakan Microsoft Office, menggunakan software Akuntansi, dan menggunakan media sosial.

2) Tidak terdapat perbedaan kompetensi antara alumni PS D-IV Akuntansi PNP tahun 2019 dan 2020.

Keterbatasan penelitian ini sebagai berikut:

1) Pendekatan penelitian hanya menggunakan metode kuantitatif sehingga kurang mengelaborasi gap kompetensi yang dirasakan oleh alumni.

2) Instrumen penelitian tidak dikelompokkan berdasarkan kebutuhan kompetensi pada berbagai bidang pekerjaan Akuntansi. Dengan demikian, kompetensi yang dibutuhkan pada berbagai bidang pekerjaan Akuntansi kurang terlihat jelas.

Adapun saran berdasarkan hasil penelitian ini sebagai berikut:

1) Penelitian selanjutnya yang akan mengkaji permasalahan serupa diharapkan lebih bisa mengelaborasi gap dan kebutuhan kompetensi sesuai bidang pekerjaan Akuntansi lainnya dengan metode kualitatif atau mixed-method.

2) Bagi mahasiswa Jurusan Akuntansi diharapkan bisa mengetahui potensi diri dan membekali dirinya dengan kompetensi yang dibutuhkan agar lebih siap saing di dunia kerja.

3) Bagi Jurusan Akuntansi Politeknik Negeri Padang diharapkan bisa melakukan penyesuaian kurikulum sesuai kebutuhan di dunia kerja serta melakukan perbaikan kualitas sistem pendidikan dan pembelajaran.

4) Bagi pengguna lulusan diharapkan mengomunikasikan kebutuhan kompetensi yang dibutuhkan di dunia kerja sesuai bidang pekerjaan, misalnya diberikan kesempatan PKL di perusahaan ataupun mengadakan seminar

\section{Referensi}

[1] Abayadeera, N., \& Watty, K. (2014). The Expectation-Performance Gap in 
Generic Skills in Accounting Graduates Evidence from Sri Lanka. Asian Review of Accounting, 22(1), 56-72. https://doi.org/10.1108/ARA-09-2013-0059

[2] Badan Pusat Statistik. (2021). Buletin Resmi Statistik Keadaan Ketenagakerjaan Indonesia Februari 2021. 19(37), 1-28. www.bps.go.id

[3] Boyatzis, R. E. (2008). Competencies in the 21st Century. Journal of Management Development, 27(1), 5-12. https://doi.org/10.1108/02621710810840730

[4] Bui, B., \& Porter, B. (2010). The Expectation-Performance Gap in Accounting Education: An Exploratory Study. Accounting Education: An International, 19(1-2), 23-50. https://doi.org/10.1080/09639280902875556

[5] FASB. (1980). Statement of Financial Accounting Concepts No. 2 - Qualitative Characteristics of Accounting Information. FASB Concepts Statements, 2, 0.

[6] IAI. (2014). Kejar Ketertinggalan Akuntan di ASEAN, IAI Siapkan Sertifikasi dan Penataan Profesi. Siaran Pers - IAI ICAEW Seminar. http://iaiglobal.or.id/v03/berita-kegiatan/detailberita-895=siaran-pers--iaiicaew-seminar-

[7] Jackling, B., \& De Lange, P. (2009). Do Accounting Graduates ' Skills Meet The Expectations of Employers? A Matter of Convergence or Divergence. Accounting Education, 18(4-5), 369-385. https://doi.org/10.1080/09639280902719341

[8] Kavanagh, M. H., \& Drennan, L. (2008). What Skills and Attributes does an Accounting Graduate Need? Evidence from Student Perceptions and Employer Expectations. Accounting and Finance, 48, 279-300. http://www.scribd.com/doc/17320277/What-skills-and-attributes-does-anaccountinggraduate-\%5CnNeed-Evidence-from-student-perceptions-andemployer-expectations

[9] Klibi, M. F., \& Oussii, A. A. (2013). Skills and Attributes Needed for Success in Accounting Career: Do Employers ' Expectations Fit with Students ' Perceptions? Evidence from Tunisia. International Journal of Business and Management, 8(8), 118-132. https://doi.org/10.5539/ijbm.v8n8p118

[10] Kurniawan, R. (2016). Keterampilan dan Atribut yang dibutuhkan oleh Lulusan Akuntansi Untuk Sukses Berkarir: Pengujian Persepsi Senjangan Persepsi Mahasiswa dan Pemberi Kerja. Jurnal Riset Akuntansi Terpadu, 9(2), 161-178.

[11] Low, M., Botes, V., Rue, D. Dela, \& Allen, J. (2016). Accounting Employers ' Expectations - The Ideal Accounting Graduates. E-Journal of Business Education \& Scholarship of Teaching, 10(1), 36-57.

[12] Muhson, A., Wahyuni, D., Mulyani, Supriyanto, \& Endang. (2012). Analisis Relevansi Lulusan Perguruan Tinggi Dengan Dunia Kerja. Jurnal Economia, 8(1), 42-52.

[13] Putri, T. R. S., \& Harto, P. (2012). Persepsi Mahasiswa Akuntansi dan Akuntan Pendidik terhadap Kompetensi yang dibutuhkan Lulusan Akuntansi. Diponegoro Journal of Accounting, 1, 1-9.

[14] Singh, G. K. G., \& Singh, S. K. G. (2008). Malaysian Graduates' Employability Skills. Unitar E-Journal, 4(1), 15-45.

[15] Sudono, D., \& Lingga, G. F. (2019). Bridging Indonesia's Skills Gap Through Partnership Between Industry - Vocational Education And Training. International Labour Organization. https://www.ilo.org/jakarta/info/public/pr/WCMS_711886/lang-en/index.htm 
[16] Tempone, I., Kavanagh, M., Segal, N., Hancock, P., Howieson, B., \& Kent, J. (2012). Desirable Generic Attributes for Accounting Graduates into the Twenty-First Century: The Views of Employers. Accounting Research Journal, 25(1), 41-55. https://doi.org/10.1108/10309611211244519

[17] Vokasi, D. P. (2020). Rencana Strategis Direktorat Jenderal Pendidikan Vokasi Tahun 2020-2024. Direktorat Jenderal Pendidikan Vokasi, 1.

[18] World Economic Forum. (2017). The Global Human Capital Report 2017. In World Economic Forum.

[19] Yu, S.C., Churyk, N.T., Chang, A. (2013). Are Students Ready For Their Future Accounting Careers? Insights From Observed Perception Gaps Among Employers, Interns, and Alumni. Global Perspectives on Accounting Education 10,1-15. 